\title{
Insight into heavy metal resistome of soil psychrotolerant bacteria originating from King George Island (Antarctica)
}

\author{
Krzysztof Romaniuk ${ }^{1}$ - Anna Ciok ${ }^{1}$. Przemyslaw Decewicz ${ }^{1} \cdot$ Witold Uhrynowski $^{1} \cdot$ Karol Budzik $^{1} \cdot$ Marta Nieckarz $^{1}$. \\ Julia Pawlowska $\cdot$ Marek K. Zdanowski ${ }^{3} \cdot$ Dariusz Bartosik $^{1} \cdot$ Lukasz Dziewit $^{1}{ }^{1}$
}

Received: 8 May 2017 / Revised: 7 February 2018 / Accepted: 19 February 2018 / Published online: 28 February 2018

(c) The Author(s) 2018. This article is an open access publication

\begin{abstract}
The presence of heavy metals in Antarctica is an emerging issue, especially as (bio)weathering of metal-containing minerals occurs and human influence is more and more visible in this region. Chemical analysis of three soil samples collected from the remote regions of King George Island (Antarctica) revealed the presence of heavy metals (mainly copper, mercury, and zinc) at relatively high concentrations. Physiological characterization of over 200 heavy metal-resistant, psychrotolerant bacterial strains isolated from the Antarctic soil samples was performed. This enabled an insight into the heavy metal resistome of these cultivable bacteria and revealed the prevalence of co-resistance phenotypes. All bacteria identified in this study were screened for the presence of selected heavy metal-resistance genes, which resulted in identification of $\operatorname{ars} B(25), \operatorname{cop} A$ (3), $c z c A$ (33), and merA (26) genes in 62 strains. Comparative analysis of their nucleotide sequences provided an insight into the diversity of heavy metal-resistance genes in Antarctic bacteria.
\end{abstract}

Keywords Antarctica $\cdot$ Psychrotolerant bacteria $\cdot$ Heavy metal $\cdot$ Heavy metal resistance $\cdot$ Resistome

\section{Introduction}

Metals (and metalloids) play an integral role in metabolic processes, and many of them are required for life; however, each metal is known to have unique features and physicochemical properties that are responsible for its specific toxicological mechanisms of action (Tchounwou et al. 2012). Moreover, some metals (e.g., $\mathrm{Ag}, \mathrm{Al}, \mathrm{Au}, \mathrm{Cd}, \mathrm{Hg}$, and $\mathrm{Pb}$ )

Electronic supplementary material The online version of this article (https://doi.org/10.1007/s00300-018-2287-4) contains supplementary material, which is available to authorized users.

Lukasz Dziewit

ldziewit@biol.uw.edu.pl

1 Department of Bacterial Genetics, Faculty of Biology, Institute of Microbiology, University of Warsaw, Miecznikowa 1, 02-096 Warsaw, Poland

2 Department of Molecular Phylogenetics and Evolution, Faculty of Biology, Institute of Botany, Biological and Chemical Research Center, University of Warsaw, Zwirki i Wigury 101, 02-089 Warsaw, Poland

3 Department of Antarctic Biology, Institute of Biochemistry and Biophysics, Polish Academy of Sciences, Pawińskiego 5a, 02-106 Warsaw, Poland have no or limited biological roles and are highly cytotoxic even in trace amounts (Bruins et al. 2000).

Heavy metal-rich regions are common across our planet. This is a consequence of natural processes (e.g., [bio]weathering of metal-containing minerals, volcanic emissions, forest fires, deep-sea vents, and geysers) and anthropogenic activities (e.g., large-scale burning of fossil fuels, mining, and metal manufacturing) (Adriano 2001). To lessen the toxic effect of heavy metals, many microorganisms have developed efficient resistance mechanisms. To date, three main types of such mechanisms have been described: (i) efflux of toxic ions from bacterial cells, (ii) enzymatic transformations of metals, and (iii) incorporation of heavy metals into complexes by metal-binding proteins, which makes them less toxic to the cell (Silver and Phung le 2005; Dziewit and Drewniak 2016).

Efflux systems constitute the largest group of metalresistance mechanisms (Amiard-Triquet and Rainbow 2011). In general, they involve active transport of toxic metals from the cytoplasm, in which three main types of proteins are usually involved: (i) resistance-nodulationcell division (RND superfamily) proteins, (ii) cation diffusion facilitators (CDF family), and (iii) P-type ATPases. Heavy metal resistance may also involve enzymatic 
transformations of toxic ions, involving their oxidation, reduction, methylation, and demethylation. Model examples of enzymatic detoxification systems in bacteria are mercury- and arsenate-resistance mechanisms. The third heavy metal-resistance mechanism involves intracellular sequestration of heavy metals as complexes, by small, cysteine-rich, metal-binding proteins-metallothioneins (Silver and Misra 1988; Silver et al. 1989; Nies 2003; Silver and Phung le 2005; Haferburg and Kothe 2007; Blindauer 2011; Dziewit and Drewniak 2016).

The occurrence of heavy metals at high concentrations may significantly influence the taxonomic and functional diversities of soil microbial communities (Kandeler et al. 1996, 2000). Studies of extreme, polar environments characterized by a still limited anthropogenic influence (e.g., High Arctic or Antarctica) are of great importance, as they may reveal novel genes encoding heavy metal-resistance and metabolism mechanisms, and show the role of naturally occurring microorganisms in biogeochemical cycles. The results of several studies revealed that bacteria isolated from various Arctic and Antarctic environments show resistances to various toxic, antimicrobial agents, such as antibiotics and heavy metals (De Souza et al. 2006, 2007; Lo Giudice et al. 2013; Mangano et al. 2014; Moller et al. 2014; Tomova et al. 2014; Perron et al. 2015; Rahman et al. 2015; Tomova et al. 2015; González-Aravena et al. 2016; Rodriguez-Rojas et al. 2016). However, overall knowledge on the resistome of polar bacteria is still rather limited, and the lack of a systematic approach, combining chemical, microbiological, and molecular analyses, is apparent.

The presence of heavy metals in Antarctica is an emerging issue, given both local and remote anthropogenic activities likely contributing to their presence in this region (Planchon et al. 2002; Jerez et al. 2011). However, it is worth noting, that the presence of heavy metals in Antarctic soils is (in most cases) primarily a consequence of naturally occurring (bio)geochemical weathering of terrigenous sources, i.e., metal-rich minerals (Santos et al. 2005; Dold et al. 2013). All together, it has fostered interest in heavy metalresistant bacteria as their collective metabolic activity may cause the biotransformation of toxic ions.

The aim of this study was to analyze heavy metal content, as well as the diversity of heavy metal-resistant bacteria and heavy metal-resistance genes in various Antarctic soils from regions differing in anthropogenic and zoogenic influence. For those purposes, samples of soil collected at King George Island (Antarctica) were analyzed for the presence of heavy metals, and bacteria showing resistance to these elements. Characterization of over 200 heavy metal-resistant, psychrotolerant bacterial strains revealed the prevalence of co-resistance phenotypes and provided insight into the diversity of the heavy metal-resistance genes among bacteria inhabiting Antarctic soil ecosystems.

\section{Materials and methods}

\section{Sample collection and isolation of bacteria}

Soil samples were collected in 2012 from three sites located at King George Island (Antarctica) differing in the extents of anthropogenic and zoogenic influence: (i) petroleum-contaminated soil found near the petroleum pumping and storage warehouse at the Henryk Arctowski Polish Antarctic Station-a site under constant anthropopression (GPS coordinates: $62^{\circ} 09.601^{\prime} \mathrm{S}, 58^{\circ} 28.464^{\prime}$ W), (ii) organic matter-rich soil from the Adélie penguin breeding colony (soil mixed with birds feces) - a region under strong zoogenic influence $\left(62^{\circ} 09.778^{\prime} \mathrm{S}\right.$, $58^{\circ} 27.711^{\prime} \mathrm{W}$ ) and (iii) a soil sample from the Jardine Peak-a region with no visible vegetation and no visible signs of human and animal activities $\left(62^{\circ} 09.997^{\prime} \mathrm{S}\right.$, $58^{\circ} 29.505^{\prime}$ W) (Fig. 1). Soil samples were taken from a depth of 15-20 cm, after gentle removal of the surface soil layer, and stored at $-20{ }^{\circ} \mathrm{C}$ for further study in laboratory (in Poland).

For isolation of bacteria, $1 \mathrm{~g}$ of each soil sample was taken and homogenized in $10 \mathrm{ml}$ of $0.85 \% \mathrm{NaCl}(\mathrm{pH} 7.0)$ in sterile, trace metal-free, plastic $(50 \mathrm{ml})$ falcon by mixing vigorously $\left(120 \mathrm{rpm}\right.$ for $2 \mathrm{~h}$ at $\left.15{ }^{\circ} \mathrm{C}\right)$. After waiting for $20 \mathrm{~min}$ to allow larger particles to settle, a series of supernatant dilutions were prepared in saline. Aliquots of $100 \mu \mathrm{l}$ of the respective dilutions were plated on R2A and lysogeny broth (LB) media solidified by the addition of $1.5 \%$ (w/v) agar (Sambrook and Russell 2001) and incubated at $15{ }^{\circ} \mathrm{C}$. All operations were carried out aseptically.

The inoculated plates were incubated at $15{ }^{\circ} \mathrm{C}$ for 2 weeks. After 14 days of incubation, 100 colonies from each sample were selected for taxonomical identification (based on 16S rDNA sequencing) and further characterization. The selection of the samples was based on apparent differences in size, color, shape, and other colony characteristics. If two or more strains had an identical 16S rDNA sequence and characteristics (the methodology described below), they were considered as the same strain, and only one of them was further analyzed. Ultimately, for further analyses, 216 strains were chosen, including (i) 90 from the petroleum-contaminated soil near the Arctowski station, (ii) 68 from the penguin colony, and (iii) 58 from the Jardine Peak (the strains were presented in Online Resource 1).

\section{Chemical analyses of the soil samples}

Quantitative analysis of chemical elements (Ag, Al, As, $\mathrm{Ba}, \mathrm{Ca}, \mathrm{Cd}, \mathrm{Co}, \mathrm{Cr}, \mathrm{Cu}, \mathrm{Fe}, \mathrm{K}, \mathrm{Mg}, \mathrm{Mn}, \mathrm{Mo}, \mathrm{Na}, \mathrm{Ni}, \mathrm{P}$, 


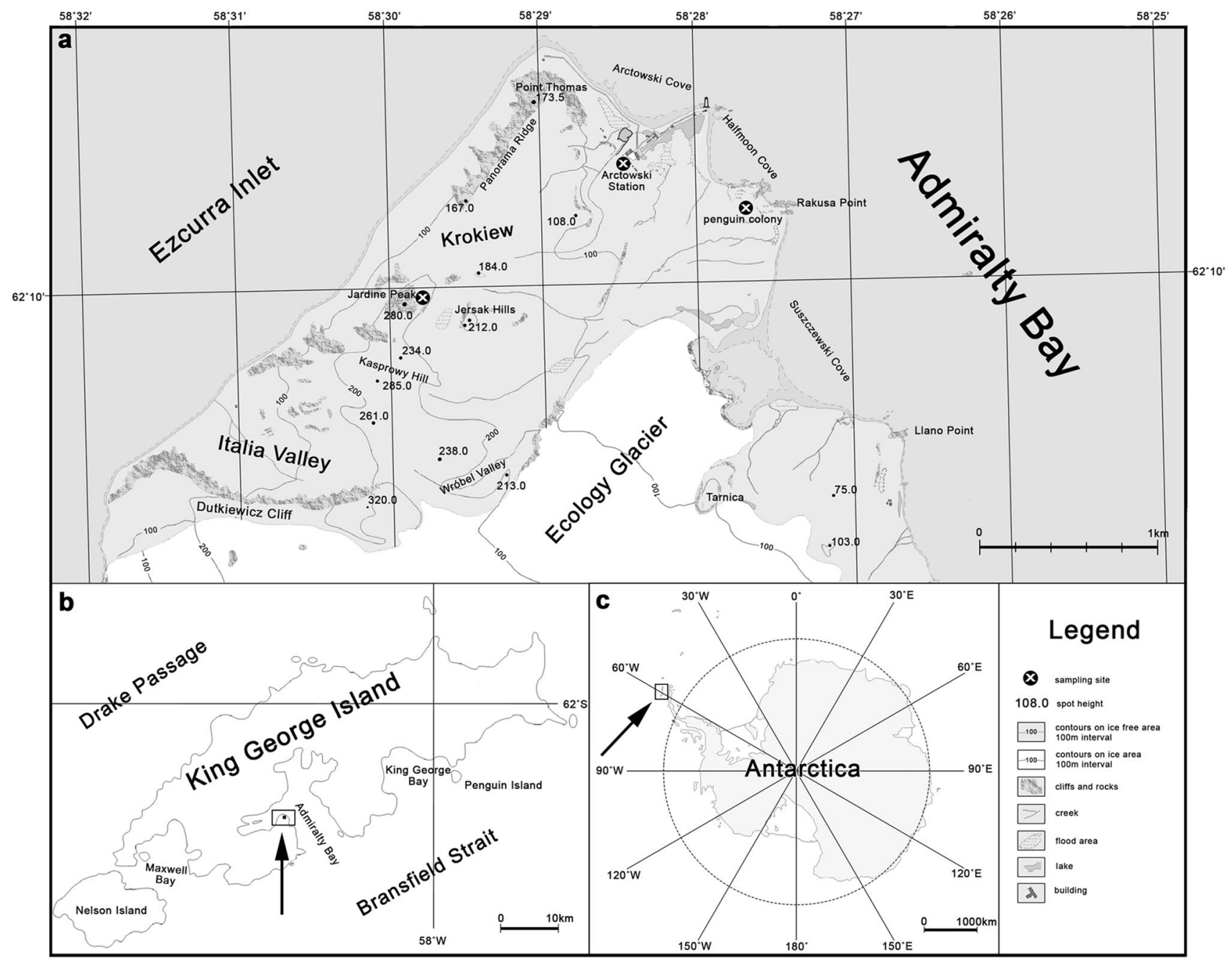

Fig. 1 Location of sampling sites on King George Island (Antarctica)

$\mathrm{Pb}, \mathrm{S}, \mathrm{Sn}, \mathrm{Sr}, \mathrm{Ti}, \mathrm{V}$, and $\mathrm{Zn}$ ) was performed with inductively coupled plasma-mass spectrometry (ICP-MS; ELAN DRC II, Perkin Elmer) and for $\mathrm{Hg}$ with atomic absorption spectroscopy (AAS) combined with AMA 254 trace mercury analyzer at the Polish Geological Institute-National Research Institute (Warsaw, Poland).

\section{Temperature, $\mathrm{pH}$, and salinity tolerance analyses}

The temperature, $\mathrm{pH}$, and salinity tolerance of each bacterial strain was assessed by measuring changes in the optical density of cultures (in comparison with the noninoculated controls) grown in 96-well plates, using an automated microplate reader (Sunrise TECAN, Tecan Trading AG, Switzerland) as was previously described (Dziewit et al. 2013). Overnight cultures were diluted in fresh LB or R2A medium with appropriate adjustments for separate assays: (i) $\mathrm{pH} 7.0$ for the temperature tolerance analysis, (ii) $\mathrm{pH} 2.0-13.0$ for the $\mathrm{pH}$ tolerance analysis, or (iii) addition of $\mathrm{NaCl}$ to the final concentration of $0.5,1,2,3,4,5,6,7,8,9,10$, or $12 \%$. In each case, initial optical density at $600 \mathrm{~nm}\left(\mathrm{OD}_{600}\right)$ was 0.05. Culture aliquots (in triplicates) were dispensed into microplates and incubated with shaking at $22{ }^{\circ} \mathrm{C}$ (for $\mathrm{pH}$ and salinity tolerance analyses) or $4,15,22,30$, or $37^{\circ} \mathrm{C}$ (for the temperature tolerance analysis) for $72 \mathrm{~h}$. The $\mathrm{OD}_{600}$ of the respective cultures was measured every $24 \mathrm{~h}$.

\section{Identification of the heavy metal-resistant strains and determination of the minimum inhibitory concentrations (MICs)}

The analytic grade salts $\left(3 \mathrm{CdSO}_{4} \times 8 \mathrm{H}_{2} \mathrm{O}, \mathrm{CoSO}_{4} \times 7 \mathrm{H}_{2} \mathrm{O}\right.$, $\mathrm{CuSO}_{4}, \mathrm{HgCl}_{2}, \mathrm{~K}_{2} \mathrm{Cr}_{2} \mathrm{O}_{7}, \mathrm{NaAsO}_{2}, \mathrm{Na}_{2} \mathrm{HAsO}_{4} \times 7 \mathrm{H}_{2} \mathrm{O}$, $\left.\mathrm{NiCl}_{2} \times 6 \mathrm{H}_{2} \mathrm{O}, \mathrm{ZnSO}_{4} \times 7 \mathrm{H}_{2} \mathrm{O}\right)$ were used in the assay as described previously (Dziewit et al. 2013). Isolates capable of growth in the presence of at least the following heavy metal ion concentrations were considered resistant: (i) $10 \mathrm{mM} \mathrm{As}(\mathrm{V})$, (ii) $1 \mathrm{mM} \mathrm{As(III),} \mathrm{Cd(II),} \mathrm{Co(II),} \mathrm{Cu(II),}$ 
$\mathrm{Ni}(\mathrm{II}), \mathrm{Zn}(\mathrm{II})$, or $\mathrm{Cr}(\mathrm{VI})$; and (iii) $0.1 \mathrm{mM} \mathrm{Hg}$ (II) (Nieto et al. 1987; Abou-Shanab et al. 2007). For the strains recognized as resistant, the exact minimum inhibitory concentrations (MICs) of selected heavy metal ions were established. As the controls for the experiment, the reliable heavy metalsensitive and -resistant strains [representing the same genera (if available) as analyzed isolates and with determined MICs for tested metals] were used.

\section{S rRNA and heavy metal-resistance genes: PCR amplification and DNA sequencing}

For each PCR reaction, the total DNA isolated from the particular strain using the Genomic Mini kit (A\&A Biotechnology, Gdynia, Poland) was used as a matrix. PCR was performed in a Mastercycler (Eppendorf, Hamburg, Germany) using HiFidelity DNA polymerase (Qiagen, Hilden, Germany; with supplied buffer), dNTP mixture, and appropriate primer pairs (Table 1). The primer pairs for the amplification of heavy metal-resistance genes were validated by means of an appropriate Python script (developed by us), enabling in silico simulation of PCR (using as a template DNA all nucleotide sequence from the NCBI database). The taxonomic specificity and the number of correct products of in silico PCR for each primer pair are presented in Online Resource 2. Then selected primer pairs were subjected to the second round of validation, in which the total DNAs of Achromobacter sp. LM16, Paracoccus sp. LM20, and Sinorhizobium sp. M14 were used as the positive controls in PCRs, as these strains previously gave positive results for the presence of particular resistance genes (Drewniak et al. 2013; Dziewit et al. 2015; Romaniuk et al. 2017).

The amplified fragments of 16S rRNA and heavy metalresistance genes of Antarctic bacteria were used as templates for DNA sequencing. The obtained sequences enabled identification of the isolated bacteria and heavy metal-resistance determinants.

Nucleotide sequences of the 16S rRNA, ars B, copA, $c z c A$, and $m e r A$ gene fragments were determined using a dye terminator sequencing kit and an automated sequencer (ABI 377 Perkin Elmer, Applied Biosystems, Waltham, USA) in the DNA Sequencing and Oligonucleotide Synthesis Laboratory at the Institute of Biochemistry and Biophysics, Polish Academy of Sciences (IBB PAS). The oligonucleotide primers used for sequencing of the particular genes are listed in Table 1.

Table 1 Primers used in this study

\begin{tabular}{|c|c|c|c|}
\hline Primer & Sequence & Amplified gene & Reference \\
\hline $27 \mathrm{f}$ & 5'-AGAGTTTGATCMTGGCTCAG-3' & 16S rRNA & Lane (1991) \\
\hline $1492 \mathrm{r}$ & 5'-TACGGYTACCTTGTTACGACT-3' & 16S rRNA & Lane (1991) \\
\hline $\operatorname{arsBF}$ & 5'-GGTGTGGAACATCGTCTGGAAYGCNAC-3' & $\operatorname{ars} B$ & Achour et al. (2007) \\
\hline $\operatorname{arsBR}$ & 5'-CAGGCCGTACACCACCAGRTACATNCC-3' & $\operatorname{ars} B$ & Achour et al. (2007) \\
\hline chrBF & 5'-GTCGTTAGCTTGCCAACATC-3' & $\operatorname{chr} B$ & Abou-Shanab et al. (2007) \\
\hline chrBR & 5'-CGGAAAGCAAGATGTCGAATCG-3' & $\operatorname{chr} B$ & Abou-Shanab et al. (2007) \\
\hline copAF & 5'-ATGTGGAACSARATGCGKATGA-3' & $\operatorname{cop} A$ & Roosa et al. (2014) \\
\hline copAR & 5'-AGYTTCAGGCCSGGAATACG-3' & $\operatorname{cop} A$ & Roosa et al. (2014) \\
\hline czcAF & 5'-TCGACGGBGCCGTGGTSMTBGTCGAGAA-3' & $c z c A$ & Roosa et al. (2014) \\
\hline czcAR & 5'-GTVAWSGCCAKCGGVBGGAACA-3' & $c z c A$ & Roosa et al. (2014) \\
\hline czcDF1 & 5'-TCATCGCCGGTGCGATCATCA -3' & $c z c D$ & Roosa et al. (2014) \\
\hline czcDR1 & 5'-TGTCATTCACGACATGAACC-3' & $c z c D$ & Roosa et al. (2014) \\
\hline czcDF2 & $\begin{array}{l}\text { 5'-TTTAGATCTTTTACCACCATGGGCGCAGGTCACTCA } \\
\text { CACGACC-3' }\end{array}$ & $c z c D$ & Abou-Shanab et al. (2007) \\
\hline czcDR2 & $\begin{array}{l}\text { 5'-TTTCAGCTGAACATCATACCCTAGTTTCCTCTGCAG } \\
\text { CAAGCGACTTC-3' }\end{array}$ & $c z c D$ & Abou-Shanab et al. (2007) \\
\hline merAHF & 5'-CCATCGGCGGCACYTGCGTYAA-3' & merA & Wang et al. (2011) \\
\hline merAHR & 5'-CGCYGCRAGCTTYAAYCYYTCRRCCATYGT-3' & merA & Wang et al. (2011) \\
\hline merALF & 5'-CGTSAACGTSGGSTGCGTGCCSTCCAAG-3' & merA & Wang et al. (2011) \\
\hline merALR & 5'-CGAGCYTKARSSCYTCGGMCAKSGTCA-3' & merA & Wang et al. (2011) \\
\hline nccAF & 5'-TTYAGCCAGGTVACSGTSATYTT-3' & $n c c A$ & Roosa et al. (2014) \\
\hline nccAR & 5'-GCYGCRTCSGCRCGCACCAGRTA-3' & $n c c A$ & Roosa et al. (2014) \\
\hline
\end{tabular}

$A$ adenine, $T$ thymine, $C$ cytosine, $G$ guanine, $R$ adenine or guanine, $Y$ cytosine or thymine, $S$ guanine or cytosine, $W$ adenine or thymine, $K$ guanine or thymine, $M$ adenine or cytosine, $B$ cytosine, thymine or guanine, $V$ adenine, cytosine or guanine, $N$ any base 


\section{Bioinformatic analysis}

Similarity searches were performed using the BLAST programs (Altschul et al. 1997) provided by the NCBI (http:// blast.ncbi.nlm.nih.gov/Blast.cgi). Bacterial strains were taxonomically assigned using the Ribosomal Database Project (RDP) classifier (Wang et al. 2007). Phylogenetic analyses were conducted using the MEGA6 package (Tamura et al. 2013), applying the maximum-likelihood algorithm (with the Tamura-Nei model) and 1000 bootstrap replicates. Sequence alignments were prepared applying ClustalW algorithm (Chenna et al. 2003).

\section{Statistical analysis}

In order to check whether sampling sites may be discriminated according to metal concentrations in soil and MIC values (for particular heavy metal) of identified bacteria, principal component analysis (PCA) was performed. For the PCA, both datasets were normalized. Heavy metal concentrations were divided by the highest observed value for particular heavy metal concentration, while MIC values were normalized using the Z-score normalization. Such datasets were provided to prcomp function in R to perform PCA on Pearson correlation matrices with centering set to True. Graphs were prepared with the ggfortify v0.4.1 R package (Tang et al. 2016).

The differences in mean values of bacterial resistance to particular metals (measured as normalized MICs) between three sites were tested. After the performance of the Shapiro-Wilk tests for normality for each variant separately, the nonparametric Kruskal-Wallis' test (K-W, one-way Anova by ranks) was chosen as an appropriate method of comparison (for groups of unequal size). The analysis of differences in mean values of resistance for subsequent pairs of data was performed in R, using kruskal.test function.

\section{Nucleotide sequence accession numbers}

All 16S rDNA sequences determined in this study have been deposited in the GenBank database with the accession numbers KY405842-KY406057 listed in Online Resource 1. The nucleotide sequences of the fragments of heavy metal-resistance genes have been deposited in GenBank with respective accession numbers KY406117-KY406141 (for the arsB gene), KY406142-KY406144 (for copA), KY406058-KY406090 (for $c z c A$ ), and KY406091-KY406116 (for merA).

\section{Results}

\section{Chemical characterization of the sampling sites}

Soil samples were collected from three locations on King George Island (Antarctica) that were subjected to similar weather conditions, of which permanent cold is the most characteristic factor (Fig. 1). In February 2012, when the samples were taken, the average air temperature was $2.0^{\circ} \mathrm{C}$ (with the maximal and minimal air temperature of 7.1 and $-5.0^{\circ} \mathrm{C}$, respectively). The mean relative humidity was $78.7 \%$, and average wind speed was $4.5 \mathrm{~m} \mathrm{~s}^{-1}$ (Arazny et al. 2013). All three sampling sites differed in the extents of anthropogenic and zoogenic influence, as mentioned above.

The concentrations of 25 elements (Ag, Al, As, Ba, Ca, $\mathrm{Cd}, \mathrm{Co}, \mathrm{Cr}, \mathrm{Cu}, \mathrm{Fe}, \mathrm{Hg}, \mathrm{K}, \mathrm{Mg}, \mathrm{Mn}, \mathrm{Mo}, \mathrm{Na}, \mathrm{Ni}, \mathrm{P}, \mathrm{Pb}, \mathrm{S}$, $\mathrm{Sn}, \mathrm{Sr}, \mathrm{Ti}, \mathrm{V}$, and $\mathrm{Zn}$ ) in soil samples from all locations were analyzed (Online Resource 3). The highest heavy metal concentrations were observed in petroleum-contaminated soil samples (from the Arctowski station), with especially high concentration of zinc (1245 $\mathrm{\mu g} \mathrm{g}^{-1}$; almost 10-fold higher compared to other samples) and mercury $\left(2.23 \mu \mathrm{g} \mathrm{g}^{-1}\right.$; over 30 -fold and 300-fold higher than in the soil from the penguin colony and the Jardine Peak, respectively). Relatively high concentrations of heavy metals (with a surprisingly elevated concentration of copper $\left[188 \mu \mathrm{g} \mathrm{g}^{-1}\right]$ compared to other samples) were also observed in samples originating from the penguin colony. In the soil sample originating from the Jardine Peak, the heavy metal concentrations were generally lower compared to other analyzed samples (Table 2).

Using publicly available data (Curtosi et al. 2010; Guerra et al. 2011; Lee et al. 2012; Laluraj et al. 2014; Vodopivez et al. 2014; Grotti et al. 2015; Kim et al. 2015), we compared the concentrations of eight heavy metals (As, $\mathrm{Cd}, \mathrm{Co}, \mathrm{Cr}$, $\mathrm{Cu}, \mathrm{Hg}, \mathrm{Ni}$, and $\mathrm{Zn}$ ) in 15 samples originating from different Antarctic regions (including five soil samples, eight marine/surface sediments samples and two snow/ice samples). Seven samples originated from King George Island. Comparative analyses revealed that, in samples from the Arctowski station and the penguin breeding colony, noticeably higher concentrations of cadmium (3.3 and $1.3 \mu \mathrm{g} \mathrm{g}^{-1}$, respectively) and especially zinc (1245 and $189 \mu \mathrm{g} \mathrm{g}^{-1}$, respectively) were observed. In addition, in all three environments investigated in this study, relatively high concentrations of copper were observed (Table 2). 


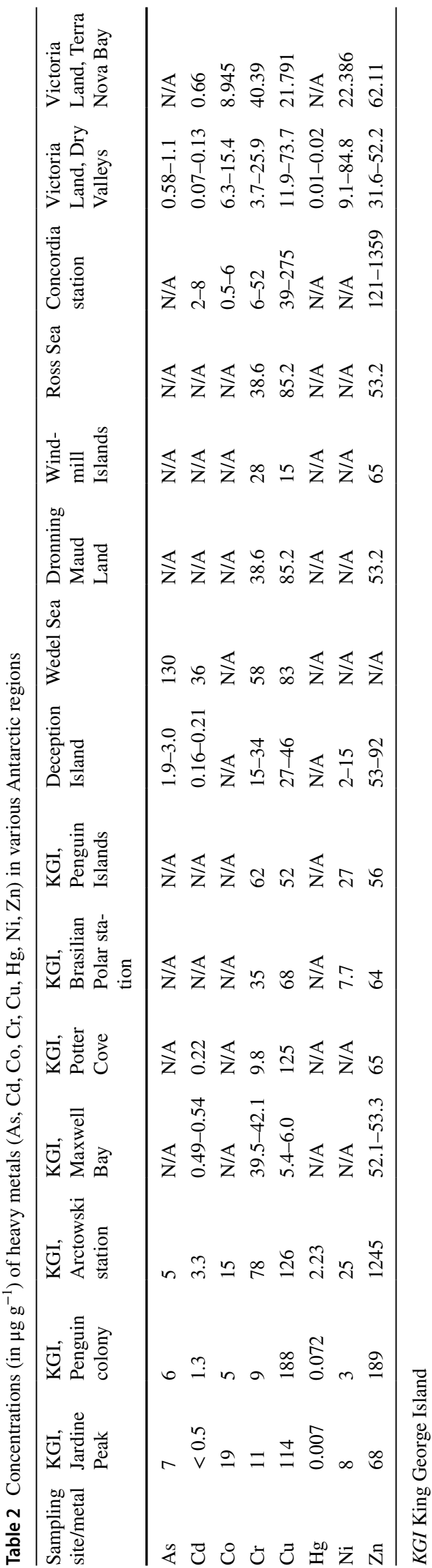

\section{Identification and physiological characterization of bacterial strains isolated from Antarctic soil samples}

In total, 216 various cultivable bacterial strains were obtained from the three soil samples analyzed in this work (Online Resource 1). Their identification was performed by $16 \mathrm{~S}$ rDNA amplification and its subsequent sequencing. Among the isolated strains, there were $54(25 \%)$ Gram-positive and $162(75 \%)$ Gram-negative bacteria.

The highest number of isolates (90) was obtained from the petroleum-contaminated soil collected within the region of the Arctowski station. Strains originating from this environment also showed the highest taxonomical diversity, as there were representatives of six Gram-negative (Brevundimonas, Chryseobacterium, Pedobacter, Pseudomonas, Psychrobacter, and Sphingomonas) and six Gram-positive (Arthrobacter, Cryobacterium, Microbacterium, Planococcus, Rhodococcus, and Sporosarcina) genera. Among the identified bacteria, the representatives of Arthrobacter spp. (36 strains; 40\%) dominated (Fig. 2).

In two other habitats, the diversity of cultivable bacteria was limited to four genera. From the Jardine Peak, 58 strains, representing exclusively Gram-negative bacteria (of genera: Flavobacterium, Janthinobacterium, Polaromonas, and Pseudomonas) were isolated, including 42 isolates of Pseudomonas spp. (72.4\%), which constituted the dominant genus. From the Adélie penguin colony, 68 isolates (representing genera: Arthrobacter, Carnobacterium, Flavobacterium, and Psychrobacter), with Psychrobacter spp. (51 strains; $75 \%$ ) as the most represented genus, were obtained (Fig. 2).

The physiological analyses revealed that the majority of the strains (162) were psychrotolerant according to the definition by Morita (Morita 1975), as they were able to grow at temperatures ranging from 4 to $30^{\circ} \mathrm{C}$, and their optimal growth temperature was 15 or $22{ }^{\circ} \mathrm{C}$. Much fewer strains (54), mostly originating from the Arctowski station, had a broader temperature tolerance and were capable of growing even at $37{ }^{\circ} \mathrm{C}$ (Online Resource 1, Online Resource 4).

The analysis of $\mathrm{pH}$ tolerance revealed that majority of strains were alcaliphilic (127), and they could tolerate $\mathrm{pH}$ up to 11.0. There were also several strains capable of growth within an extremely broad range of $\mathrm{pH}$, e.g., Psychrobacter sp. ANT_H9 which tolerates $\mathrm{pH}$ between 2.0 and 12.0, with the optimum at 9.0 (Online Resource 1, Online Resource 4).

The salinity tolerance test showed that strains from the Jardine Peak are much more sensitive to $\mathrm{NaCl}$ than the strains from the other two locations. Only 55\% of them were capable of growth in a medium with $3 \% \mathrm{NaCl}$ concentration, and only one strain was able to survive when the $\mathrm{NaCl}$ concentration reached $6 \%$. In turn, only $9(10 \%)$ and $3(4.4 \%)$ of the strains originating from the Arctowski station and the 
Fig. 2 Taxonomic classification of the bacterial isolates from the Antarctic soil samples. The number of isolates belonging to the particular genus in each analyzed environment (the Jardine Peak, Arctowski station and penguin colony) is presented. Taxonomical identification was performed by $16 \mathrm{~S}$ rDNA amplification and its subsequent sequencing

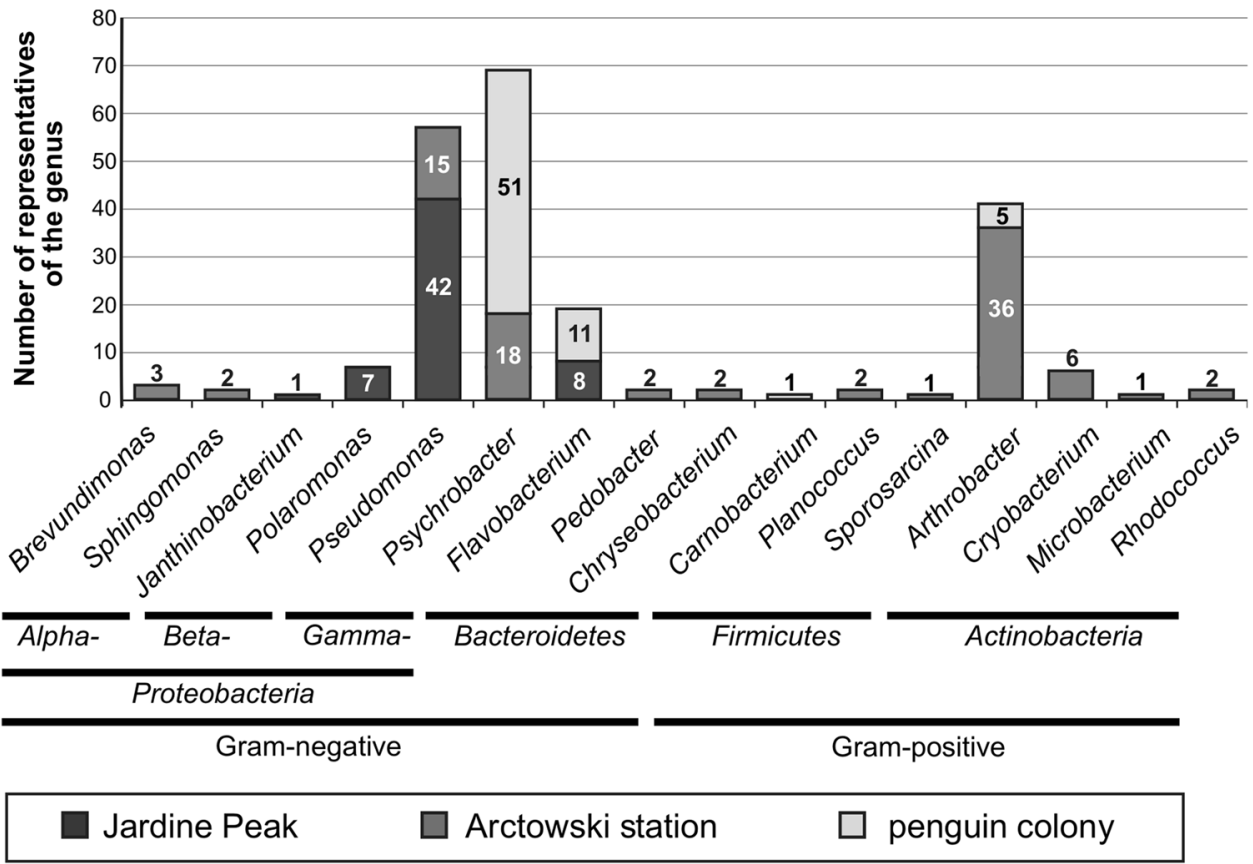

penguin colony, respectively, were incapable of growing in a medium containing $3 \% \mathrm{NaCl}$. Moreover, there were three strains from the Arctowski station and 2 strains from the penguin colony which should be considered as halotolerants, since they efficiently grew in a medium with $10 \% \mathrm{NaCl}$ (Online Resource 1, Online Resource 4).

\section{Identification of bacteria resistant to heavy metals and determination of the minimal inhibitory concentrations of these metals}

In the first stage of the analysis, the 216 selected bacterial isolates were screened for the presence of various heavy metalresistance phenotypes. It is worth noting, that in the performed analysis, high cut-off values were used for identification of metal-resistant strains [based on the reference studies (Nieto et al. 1987; Abou-Shanab et al. 2007)] to reduce the possibility of obtaining false-positive results. A strain was recognized as resistant to a particular heavy metal ion when it was capable of growing at the following ion concentrations: (i) $10 \mathrm{mM}$ As(V); (ii) 1 mM As(III), Cd(II), Co(II), Cu(II), Ni(II), Zn(II), or $\mathrm{Cr}$ (VI); and (iii) $0.1 \mathrm{mM} \mathrm{Hg}$ (II) (Nieto et al. 1987; AbouShanab et al. 2007). In total, 585 (out of 1800 tested) resistance phenotypes were identified. Most of the strains (75\%) showed resistance to at least two heavy metals $(86,30$, and 46 from the Arctowski station, penguin colony, and Jardine Peak, respectively), and 37 strains exhibited resistance to five or more of tested metals (Fig. 3a). Among the resistant bacteria, Psychrobacter sp. ANT_P7 from the penguin colony showed the highest number (7) of resistance phenotypes, as it
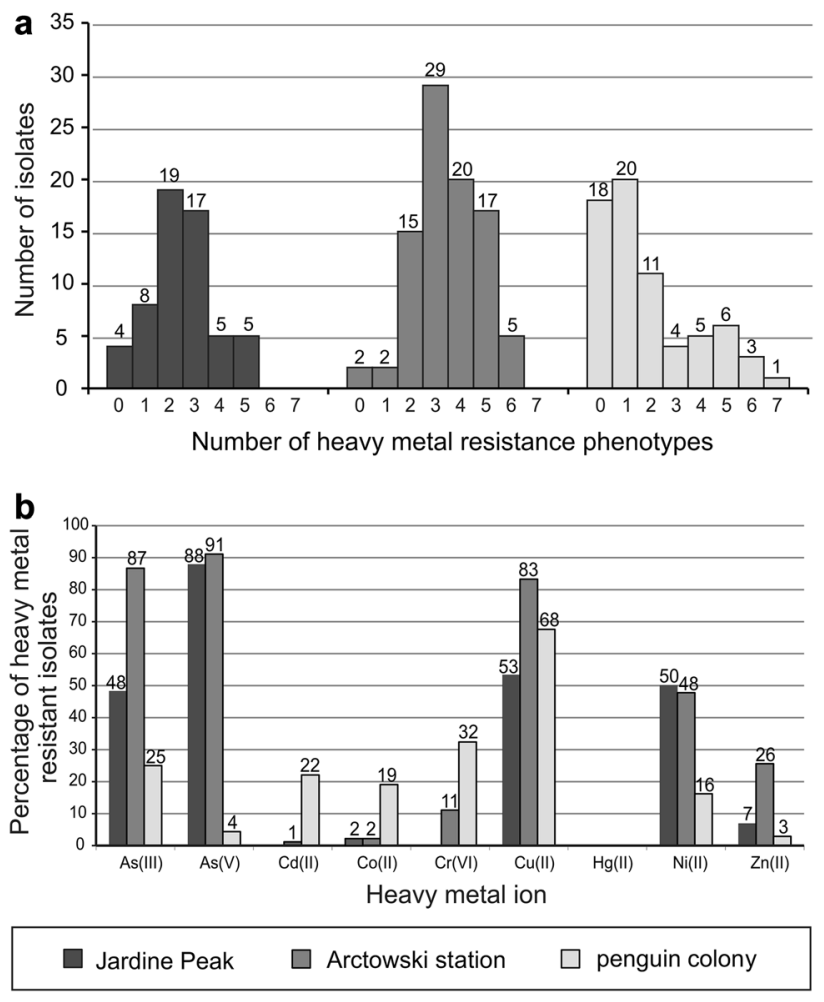

Fig. 3 Number of heavy metal-resistance phenotypes exhibited by 216 analyzed Antarctic bacteria (a), and percentage of bacterial isolates resistant to the particular heavy metal ion in bacteria originating from soil samples collected at the Jardine Peak, Arctowski station, and penguin colony (b) 
could tolerate high concentrations of $\mathrm{As}(\mathrm{III}), \mathrm{Cd}(\mathrm{II}), \mathrm{Co}(\mathrm{II})$, $\mathrm{Cr}(\mathrm{VI}), \mathrm{Cu}(\mathrm{II}), \mathrm{Ni}(\mathrm{II})$, and $\mathrm{Zn}$ (II) (Online Resource 1).

The majority of bacterial strains analyzed in this study were resistant to $\mathrm{Cu}(\mathrm{II})$ (147 isolates), $\mathrm{As}(\mathrm{V})$ (135), and As(III) (123). These strains mostly originated from the Arctowski station and the Jardine Peak. However, many of the strains isolated from the penguin colony (68\%) also showed $\mathrm{Cu}$ (II) resistance (Fig. 3b). Moreover, 115 (53.2\%) of the analyzed bacteria exhibited the As:Cu co-resistance phenotype. A large number of strains could also tolerate elevated concentrations of nickel (83 isolates in total, 50 and $48 \%$ of the strains from the Jardine Peak and Arctowski station, respectively). Much fewer isolates were resistant to cadmium (16), cobalt (16), and chromium (32) - mainly from the penguin colony, as well as zinc (29)-mostly strains from the Arctowski station, where $\mathrm{Zn}$ concentration is extremely high (Fig. 3b).

In the second stage of the analysis, the exact MICs of the particular heavy metals for the identified resistant strains were determined (Online Resource 1). High level resistance to arsenite (with the average of $5.1 \mathrm{mM}$ for 123 arsenite resistant strains) and arsenate $(218.9 \mathrm{mM}$ for 135 resistant strains) was observed. In turn, in the case of $\mathrm{Cu}(\mathrm{II})$, the medium level resistance (with the average of $3.5 \mathrm{mM}$ for 147 resistant strains) was revealed. Finally, low level resistances to $\mathrm{Cd}(\mathrm{II}), \mathrm{Co}(\mathrm{II}), \mathrm{Cr}(\mathrm{VI}), \mathrm{Ni}(\mathrm{II})$, and $\mathrm{Zn}(\mathrm{II})$, with respective averages of 2.0, 2.3, 2.5, 2.8, and $2.6 \mathrm{mM}$ (considering only the strains resistant to particular heavy metals), were observed.

The highest MIC values for As(III), As(V), and $\mathrm{Cu}(\mathrm{II})$ (for which high or medium level resistances were observed) were found in strains originating from the petroleum-contaminated soil sample. These included Arthrobacter sp. ANT_H51B showing extremely high resistance to arsenite $(\mathrm{MIC}=18 \mathrm{mM})$, Cryobacterium $\mathrm{sp}$. ANT_H25B-to arsenate $(1000 \mathrm{mM})$, and Arthrobacter spp. ANT_H5, ANT_H17B, and ANT_H49B-to Cu(II) (8 mM) (Online Resource 1).

\section{Distribution of the heavy metal-resistance genes in the analyzed pools of bacteria}

The total DNAs isolated from each bacterial strain (216 isolates in total) were used as the templates in PCR-based detection of heavy metal-resistance genes most commonly identified in microbial genomes: ars $B$ gene (encoding arsenic efflux pump), $c z c A$ (inner membrane protein contributing to cobalt, zinc, and cadmium efflux), $c z c D$ (single membrane polypeptide chemiosmotic efflux pump conferring resistance to cobalt, zinc, and cadmium), $\operatorname{chrB}$ (chromate-resistance protein), copA (P-type copper efflux ATPase), merA (mercuric reductase), and $n c c A$ (membrane protein conferring resistance to cobalt, cadmium, and nickel) (Silver and Phung le 2005).

Obtained PCR products were purified and sequenced. The specific PCR products were obtained for four genes, i.e., ars $B, c z c A, \operatorname{cop} A$, and merA. Both primer pairs for the amplification of the $c z c D$ gene [one of the most commonly distributed resistance genes in bacteria (Silver and Phung le 2005)] were not sufficiently specific, as the nucleotide sequences of the DNA fragments amplified by PCR did not show any similarities with the pool of reference $c z c D$ genes [retrieved from the BacMet database (Pal et al. 2014) and the NCBI database]. The best BLASTx hits (of these, PCR product sequences against the NCBI database) matched transcriptional activator NhaR (of Pseudomonas viridiflava, acc. no. WP_025993958) and glucose dehydrogenase (of Pseudomonas coronafaciens, acc. no. KGS11499). This result did not unequivocally exclude the possibility that the $c z c D$ genes were present within the genomes of the analyzed pool of Antarctic bacteria. To elucidate this problem, novel PCR primers should be designed, and this will be the aim of our future work. For the primer pairs specific to $n c c A$ and $c h r B$ genes, no PCR products were obtained, which might indicate that they are missing in the genomes of the studied bacteria, and the observed resistance phenotypes were driven by other systems or the resistance was rather "nonspecific" and resulted from, e.g., altered cell envelope permeability or biofilm formation (Wales and Davies 2015). This may also be the explanation for the $\mathrm{As}(\mathrm{III}), \mathrm{As}(\mathrm{V}), \mathrm{Cd}(\mathrm{II}), \mathrm{Co}(\mathrm{II})$, $\mathrm{Cu}(\mathrm{II})$, and $\mathrm{Zn}$ (II) resistance of strains in which the presence of specific genes involved in resistance to these metals, i.e., $\operatorname{ars} B, c z c A$, and $\operatorname{cop} A$, could not be shown by PCR screening.

In total, 87 heavy metal-resistance genes were identified. The highest number (63) of them was identified in the petroleum-contaminated soil (from the Arctowski station). In bacteria originating from the Jardine Peak, 21 resistance genes were identified, while, surprisingly, in bacteria isolated from the soil samples collected in the penguin colony, only two strains, Psychrobacter sp. ANT_P15B and Psychrobacter $\mathrm{sp}$. ANT_P17, were positive for the merA and merA plus $c z c A$ genes, respectively (Fig. 4).

Only two strains within the analyzed pool (Psychrobacter sp. ANT_H24 and Psychrobacter sp. ANT_H29) were shown to carry three types of resistance genes (i.e., $\operatorname{ars} B, c z c A$, and $m e r A$ ), while two or one type of resistance genes were identified in 19 (8.8\%) and 41 (19\%) isolates, respectively.

The highest number (33) of specific PCR products was obtained in the case of the $c z c A$ genes (the Jardine Peak [11 sequences from bacteria belonging to Pseudomonas and Polaromonas genera], petroleum-contaminated soil [21 sequences of Arthrobacter, Brevundimonas, Pseudomonas, Psychrobacter, and Sphingomonas genera], and the penguin colony [1 sequence of Psychrobacter sp. ANT_P17]). For 


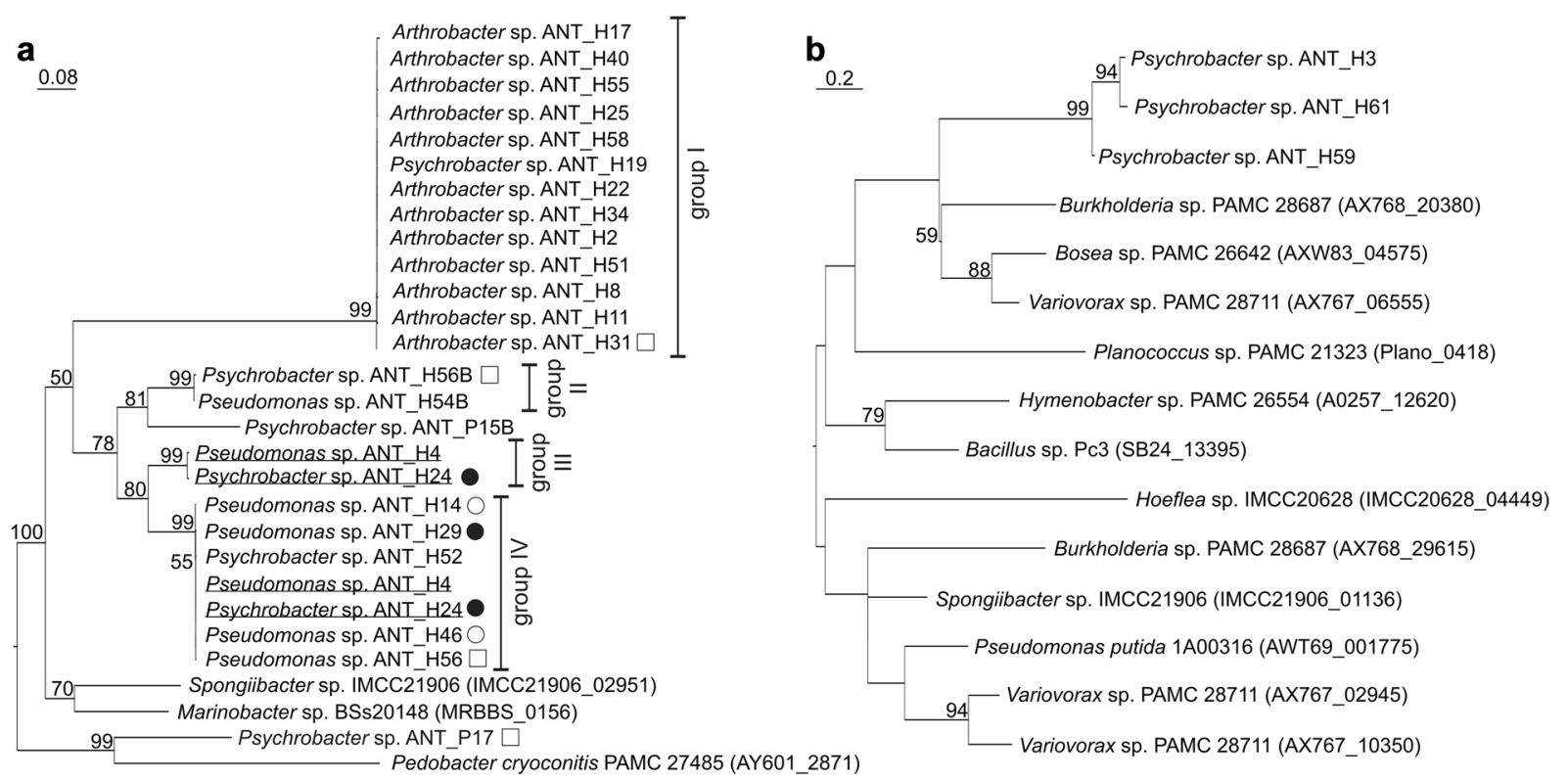

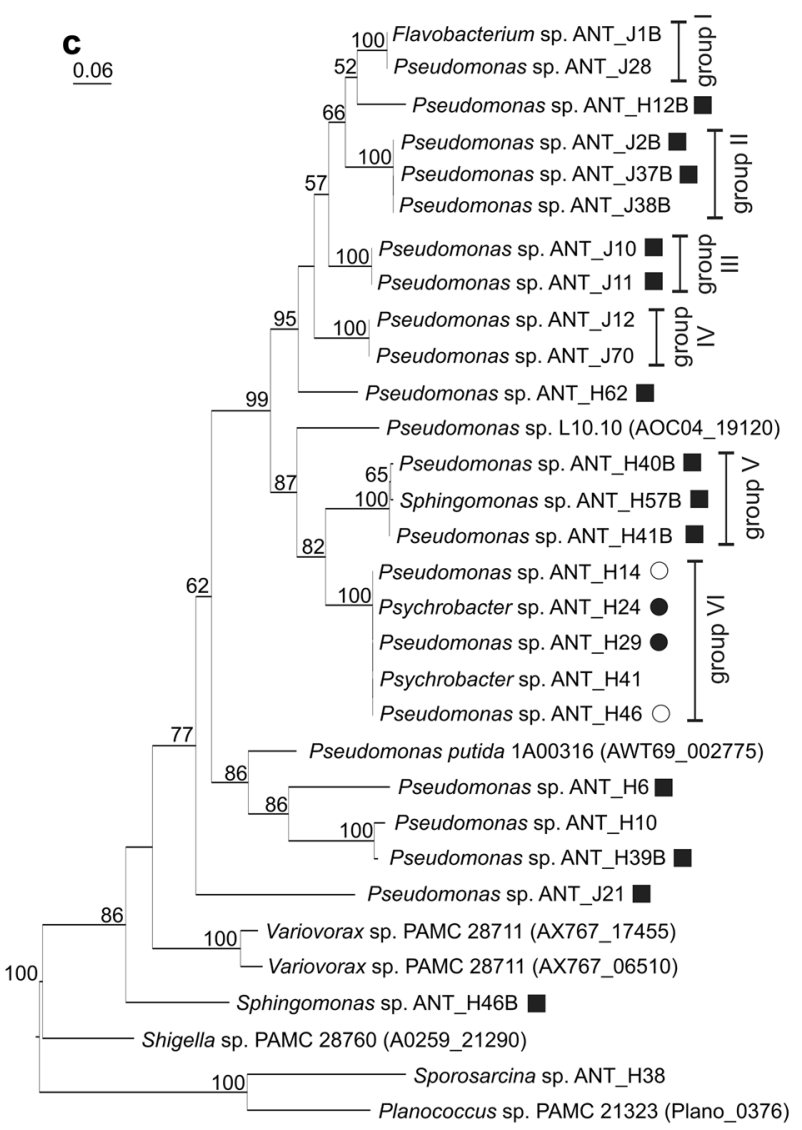

Fig. 4 The phylogenetic trees showing the diversities of merA (a), $\operatorname{cop} A(\mathbf{b}), \operatorname{ars} B(\mathbf{c})$, and $c z c A(\mathbf{d})$ genes detected in various psychrotolerant bacteria. The unrooted trees were constructed using the maximum-likelihood algorithm (with the Tamura-Nei model), and statistical support for internal nodes was determined by 1000 bootstrap replicates. Values of $>50 \%$ are shown. Locus tags for the reference genes, retrieved from the genomes of psychrotolerant bacteria

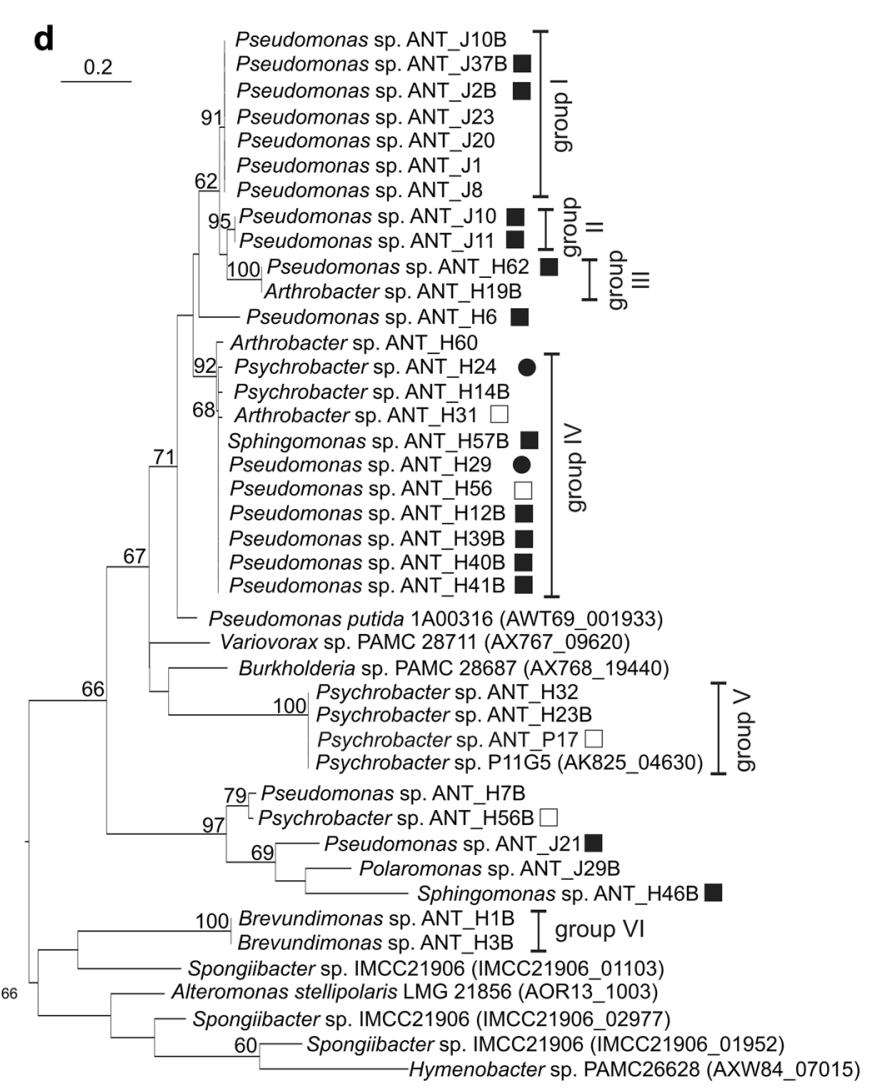

and used for the phylogenetic analysis, are given in parentheses. The strains carrying two different merA genes are underlined. The strains carrying three resistance genes (i.e., $\operatorname{ars} B, c z c A$, and $m e r A$ ) are indicated by a black dot. The strains carrying ars $B$ and mer $A$ genes are indicated by a white dot; $\operatorname{ars} B$ and $c z c A-$ a black square; $c z c A$ and merA—a white square 
the merA genes, 26 specific PCR products (the Arctowski station [24 of the Arthrobacter, Pseudomonas, and Psychrobacter genera], and the penguin colony [2 of the Psychrobacter genus]) were obtained, and slightly less for the $\operatorname{ars} B$ genes-25 in total (the Jardine Peak [10 of the Pseudomonas and Flavobacterium genera], and the Arctowski station [15 of the Pseudomonas, Psychrobacter, Sphingomonas, and Sporosarcina genera]). The copA genes have been detected only in three Psychrobacter strains isolated from the Arctowski station.

The analysis revealed that $11 \%$ of the bacterial strains analyzed in this work carried the merA genes. Interestingly, none of the bacterial isolates analyzed in this work was recognized as mercury resistant. It is possible that the identified merA genes conferred low level resistance to mercury [lower that the cut-off value $(0.1 \mathrm{mM})$ used for identification of Hg-resistant strains in this study]. This seems to be a reasonable explanation as the chemical analysis revealed that the highest $\mathrm{Hg}$ concentration $\left(2.23 \mu \mathrm{g} \mathrm{g}^{-1}\right)$ was detected in soil from the Arctowski station, where the majority of bacteria carrying the merA genes was identified. Nevertheless, this was still almost 10-times lower than the cut-off value used in this and other reference studies (Nieto et al. 1987).

The lack of transparent correlation between the presence of particular resistance genes and the resistance phenotype was also observed for the $c z c A$ (only $30 \%$ of isolates carrying this gene conferred resistance to zinc, cobalt, or cadmium) and $\operatorname{ars} B$ ( $84 \%$ of isolates positive for the gene were arsenic resistant) genes. In the case of three Psychrobacter strains carrying the copA gene, they were all copper resistant.

\section{Diversities of arsB, copA, CzcA, and merA genes in psychrotolerant Antarctic bacteria}

The DNA sequences of the amplified and sequenced fragments of the heavy metal-resistance genes ( $\operatorname{ars} B, \operatorname{cop} A, c z c A$ and $m e r A$ ) were used for comparative analyses. In these analyses, the reference genes found in the genomes of bacteria defined as psychrotolerants (in the NCBI database https ://www.ncbi.nlm.nih.gov/), were also included. The initial alignments (made using ClustalW algorithm and MEGA6 software) of $\operatorname{ars} B$ (31 sequences in total), copA (15), $c z c A$ (42), and merA (29) genes were manually trimmed (the final alignments were 514- [for $\operatorname{ars} B$ ], 191- [for $\operatorname{cop} A$ ], 133- [for $c z c A$ ], and 1187-position [for merA] long) and used for the construction of four phylogenetic trees (Fig. 4). Moreover, the reciprocal identity levels (i.e., percentage identities between each two nucleotide sequences in particular pool of sequences) of all analyzed gene fragments were calculated. This provided groups comprising sequences sharing at least 99\% nucleotide identity.

The analysis of the merA tree topology revealed that only one sequence identified in this work (originating from
Psychrobacter sp. ANT_P17, from the penguin colony) was clustered together with the reference gene of Pedobacter cryoconitis, while all other sequences were clustered separately, on two main tree branches, grouping 13 and 12 elements, respectively. Based on the reciprocal identity comparisons, four groups clustering the merA sequences identical in at least $99 \%$ (with $95 \%$ query coverage) were distinguished. All these groups were heterogeneous and clustered the merA sequences found in various genera: (i) Arthrobacter spp. and Psychrobacter sp.- - groups I, and (ii-iv); Psychrobacter spp. and Pseudomonas spp.--groups II, III, and IV (Fig. 4a).

The comparative analysis of the copA genes showed that all three sequences identified in this study were clustered together, and two most divergent $\operatorname{cop} A$ sequences (originating from Psychrobacter sp. ANT_H3 and ANT_H59) shared $83 \%$ identity of their nucleotide sequences (Fig. 4b).

The analysis of the $\operatorname{ars} B$ tree topology and comparisons of the reciprocal identity levels of particular arsenic resistance genes revealed the presence of six groups clustering sequences that were at least 99\% identical. Groups II, III, and IV are homogenous and composed of the $\operatorname{ars} B$ sequences identified exclusively in Pseudomonas spp. originating from the Jardine Peak. Three other groups clustered the $\operatorname{ars} B$ sequences found in various genera: (i) Flavobacterium spp. and Pseudomonas spp.- group I, (ii) Sphingomonas spp. and Pseudomonas spp.--group V, and (iii) Pseudomonas spp. and Psychrobacter spp.- group VI. The most phylogenetically distant $\operatorname{ars} B$ sequence was found in Sporosarcina sp. ANT_H38, which represents the Terrabacteria group of Gram-positive bacteria (Fig. 4c).

The analysis of the $c z c A$ tree topology also allowed identification of six groups clustering nearly identical sequences. Groups I and II gathered the $c z c A$ sequences originating exclusively from Pseudomonas spp. from the Jardine Peak. Similarly, group VI, clustered the $c z c A$ sequences of Brevundimonas spp. from the Arctowski station. Group V, which contained four $c z c A$ sequences from Psychrobacter spp., was also homogenous, but the bacteria in this group were of different origins: two strains (ANT_H32 and ANT_ $\mathrm{H} 23 \mathrm{~B}$ ) were isolated from the petroleum-contaminated soil, the strain ANT_P17 originated from the penguin colony and the reference strain P11G5 is an Arctic marine bacterium (Moghadam et al. 2016). The remaining two groups clustered the $c z c A$ sequences found in bacteria originating from the Arctowski station and belonging to various genera: (i) Pseudomonas spp. and Arthrobacter spp.- - group III and (ii) Psychrobacter spp., Pseudomonas spp., Arthrobacter spp., and Sphingomonas spp.—group IV (Fig. 4d). 


\section{Discussion}

Antarctica is considered as a region with limited anthropogenic influence, however, even there heavy metal contamination of soil is present. It is a consequence of (bio)weathering of metal-rich minerals (Santos et al. 2005; Dold et al. 2013) as well as global atmospheric pollution (Planchon et al. 2002; Jerez et al. 2011). In this study, three remote sites at King George Island (Antarctica) were screened for heavy metal presence, as well as occurrence of heavy metalresistant bacteria and genes conferring resistance to these toxic elements.

The highest heavy metal concentrations were observed in petroleum-contaminated soil samples (collected near the Arctowski station), which is understandable as this is an anthropogenically shaped site. Interestingly, high concentrations of heavy metals (including copper) were also observed in samples originating from the penguin colony. This observation may support the hypothesis regarding the accumulation of heavy metals in bodies and excrements of penguins (and other polar animals) ingesting toxic elements during feeding in the sea (Locarnini and Presley 1995; Espejo et al. 2014).

Comparing the heavy metal concentration at three sampling sites analyzed in this work with 12 other Antarctic regions revealed that in samples from the Arctowski station and the penguin colony noticeably higher concentrations of cadmium, copper, and zinc could be found (Table 2). We also compared the concentrations of particular elements in Antarctic soils with the average content of these heavy metals in soils worldwide and the general norms for heavy metal content in soils and sediments (Kabata-Pendias and Pendias 2001; Hooda et al. 2010). This analysis confirmed that all analyzed soils are rich in copper (its concentration in samples from the Arctowski station and the penguin colony being above the acceptable norms), and zinc (especially in soils from the Arctowski station, where the norms were exceeded threefold). Moreover, detected concentrations of arsenic (in all samples), cadmium (in samples from the Arctowski station and the penguin colony), as well as mercury (in sample from the Arctowski station) are slightly above the average contents of those elements in soils worldwide (Kabata-Pendias and Pendias 2001; Hooda et al. 2010).

In this study, over 200 heavy metal-resistant, psychrotolerant bacterial strains were isolated from three soil samples. The diversity of cultivable bacteria identified in this study was biased toward Gram-negative strains, mostly belonging to the Proteobacteria phylum. This is in good agreement with several previous studies concerning identification of cultivable bacteria from Antarctica (Zdanowski et al. 2004, 2013; van Dorst et al. 2016). Notably, almost $25 \%$ of bacterial strains isolated in this study belonged to Actinobacteria phylum, and bacteria representing this group are commonly isolated from Antarctic soils (Smith et al. 2006; Zdanowski et al. 2013; Cowan et al. 2014; Pudasaini et al. 2017). Our analysis revealed a dominance of Pseudomonas spp. in soil samples from the Jardine Peak, which correlates with the results of similar analysis of cultivable bacteria performed for the soil samples from the Fildes Peninsula at King George Island (Antarctica) (Gonzalez-Rocha et al. 2017).

Applying a culture-dependent approach for bacterial diversity analysis entails several drawbacks. First of all, the obtained data are strongly biased, since only a portion of environmental bacteria can be cultivated nowadays. Moreover, media used for the isolation could be selective. Therefore, metagenomic analysis always gives a much deeper insight into the overall microbial diversity of a particular environment. On the other hand, this approach does not allow for the performance of any functional and/or phenotypic analyses of bacteria. In this study, only the culturedependent approach was applied, as we focused not only on taxonomic diversity of bacteria inhabiting Antarctic environments, but also their molecular and physiological characterization. We compared the taxonomic profiles obtained for each soil sample with the results of metagenomic analyses performed by other studies of soils from Antarctica. In the study by Wang et al. (2015), metagenomic analysis of human-, penguin-, and seal-impacted soils as well as pristine soil from the Fildes Region (Antarctica) was performed. Considering all the samples together, members of the genera Gaiella, Chloracidobacterium, Nitrospira, Polaromonas, Gemmatimonas, Sphingomonas, and Chthoniobacter were found to predominate (Wang et al. 2015). For comparison purposes, in our study, dominants were bacteria belonging to the genera Arthrobacter, Pseudomonas, and Psychrobacter, while the genera mentioned by Wang and colleagues were represented only by seven isolates of Polaromonas from the Jardine Peak and two strains of Sphinogomonas originating from the Arctowski station. In another study analyzing the taxonomic structure of a soil community at Mars Oasis on Alexander Island in the southern Maritime Antarctic, it was revealed that of the 1160 genera identified, the top ten matches were to Candidatus Solibacter, Burkholderia, Streptomyces, Xanthomonas, Pseudomonas, Sphingomonas, Planctomyces, Bradyrhizobium, Rhodopseudomonas, and Bacillus (Pearce et al. 2012). This result only partially correlates with our findings, as we have also shown that the subdominants (or dominants) in analyzed soil samples were bacteria of the genus Pseudomonas. It is also important to mention that Pearce and colleagues, based on the literature data, summarized the most frequent bacterial genera in Antarctic soils (identified in $>3$ clone-library-based or 454-based studies). These are Acidobacteria, Actinobacteria, Arthrobacter, Anabaena, Bacteroides, Brevundimonas, Chloroflexus, Cytophaga, Deinococcus, Fervidobacterium, 


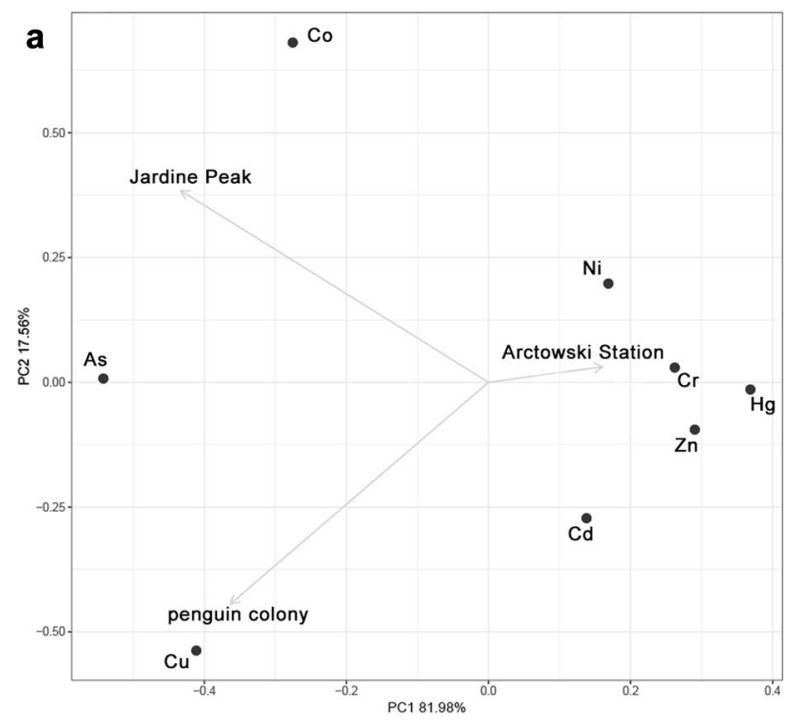

Fig. 5 Principal component analysis (PCA) of chemical (a) and biological (b) properties of the sampling sites. For the normalization of data for the PCA, heavy metal concentrations were divided by the highest observed value for particular heavy metal concentration, and MIC values for each heavy metal of identified bacteria were subjected to Z-score normalization. On panel $\mathbf{b}$, particular bacterial isolates

Friedmanniella, Hymenobacter, Leptolyngbya, Microcoleus, Microcystis, Nitrosospira, Nostoc, Oscillatoria, Phormidium, Pseudomonas, Pseudonocardia, Psychrobacter, Rhodococcus, Rubrobacter, Sphingobacterium, Sphingomonas, Sporosarcosina, Synechococcus, and Xanthomonas (Pearce et al. 2012). This summary may suggest that there is at least partial agreement between our and more highthroughput (metagenomic) analyses, as most represented genera (Arthrobacter, Pseudomonas, and Psychrobacter) isolated in our study are on the list.

Physiological analysis of bacteria performed in this study revealed the presence of 585 (32.5\%) heavy metal-resistance phenotypes. Most of them were identified in bacteria originating from petroleum-contaminated soil (the Arctowski station). In all analyzed bacteria, the most common were resistances to copper, arsenate, and arsenite. Moreover, in 162 strains co-resistance (i.e., joint resistance to at least two toxic ions) phenotypes were revealed, which indicates that this phenomenon is not restricted to bacteria originating from the heavily contaminated regions. This high number of heavy metal-resistant bacteria in the Antarctic region may be surprising; however, it is in agreement with the results of other studies (De Souza et al. 2006, 2007; Tomova et al. 2014, 2015). Moreover, the high incidence of resistance to heavy metals suggests that bacteria are able to cope and/or adapt to the occurrence of "pollutants" even in low humanimpacted environments (Lo Giudice et al. 2013).

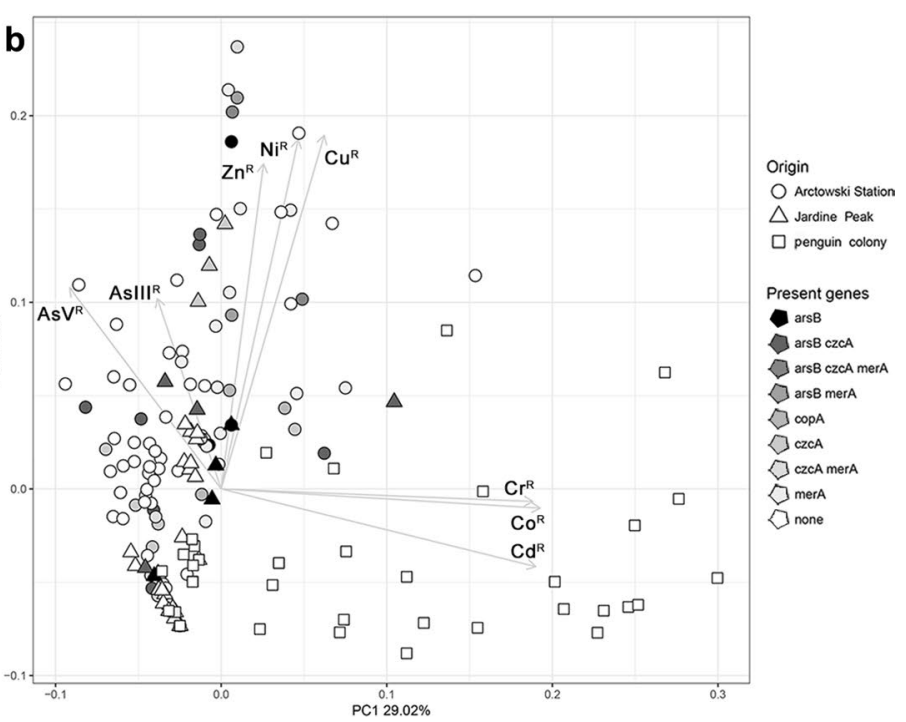

represented by either circle (bacteria originating from the Arctowski station), triangle (bacteria from the Jardine Peak), or rectangle (bacteria from the penguin colony) are filled in gray scale to show the presence of the following metal-resistance genes: $\operatorname{ars} B, \operatorname{cop} A, c z c A$, and $m e r A$, as well as their combinations. PCA eigenvectors on both panels indicate the influence of each variable on principal components

All bacterial isolates analyzed in this study were screened for the presence of heavy metal-resistance genes, which resulted in identification of 87 genetic determinants homologous to $\operatorname{ars} B, \operatorname{cop} A, c z c A$, or merA genes and showed that such genes are prevalent even in environments with limited anthropopression. This observation stays in good agreement with the results of other studies, which suggested that, e.g., merA genes are widely distributed in the environment (mainly soil), and occur frequently even in the pristine polar regions (Kelly and Reassey 1984; Moller et al. 2014; Mindlin et al. 2016). It is also worth noting that, in most cases, identified resistance genes differed significantly; however, comparative analysis of their nucleotide sequences also revealed the presence of identical genes in phylogenetically distant bacteria.

As a summarization of this work, the principal coordinates analysis was performed on matrix containing normalized concentrations of eight selected heavy metals (Co, As, $\mathrm{Cu}, \mathrm{Ni}, \mathrm{Cr}, \mathrm{Zn}, \mathrm{Hg}$, and $\mathrm{Cd}$ ) in three studied soil samples. All sampling sites differed from one another, and the Arctowski station site formed the best delimited group, characterized by high concentrations of following metals: $\mathrm{Ni}, \mathrm{Cr}, \mathrm{Zn}, \mathrm{Hg}$, and Cd (Fig. 5a). The PCA was also performed on matrix containing strains' resistances to particular heavy metals (determined as normalized MICs values) in three different sites. The first axis discriminated strains mainly according to $\mathrm{Cr}(\mathrm{VI}), \mathrm{Co}(\mathrm{II})$, and $\mathrm{Cd}(\mathrm{II})$ resistance, while the second one was mainly explained by resistance to $\mathrm{Zn}(\mathrm{II}), \mathrm{Ni}(\mathrm{II}), \mathrm{Cu}(\mathrm{II})$, 
and $\mathrm{As}(\mathrm{III})$ and $\mathrm{As}(\mathrm{V})$ (Fig. 5b). The mean values of bacterial resistance to $\mathrm{As}(\mathrm{III})$ and $\mathrm{As}(\mathrm{V})$ were significantly higher ( $p$ value $<0,05$; detailed values in Online Resource 5) for strains isolated from the Arctowski station than for those from the Jardine Peak and the penguin colony. Interestingly, genes supposed to be responsible for resistance to arsenic were detected only in some strains from the Arctowski station and the Jardine Peak (Figs. 4, 5, Online Resource 6). Similarly, the mean values of bacterial resistance to $\mathrm{Cu}$ (II) were significantly higher ( $p$ value $<0,05$; detailed values in Online Resource 5) for strains isolated from the Arctowski station compared to those from the Jardine Peak and the penguin colony soil samples. In this case, genes supposed to be responsible for resistance to $\mathrm{Cu}$ were present in only three strains from the Arctowski station. Bacterial strains isolated from the penguin colony formed the best delimited group in PCA analysis. The mean values of resistance to Cd(II) and $\mathrm{Co}(\mathrm{II})$ in this site were significantly higher ( $p$ value $<0,05$; detailed values in Online Resource 5) than in the Jardine Peak and the Arctowski station. However, $c z c A$ genes (supposed to be responsible for resistance to these metals) were not found in bacteria isolated from this soil sample (Figs. 4, 5, Online Resource 6).

It is worth mentioning that, in general, a lack of correlation between the presence of particular resistance genes and the resistance phenotype was observed. This may be explained by the possibility that some of the identified heavy metal-resistance genes are inactive, either permanently due to the presence of mutation or facultatively (only in a particular host) as a result of genetic incongruity, which was previously shown for several other resistance module-bacterial host systems (Dziewit et al. 2013, 2015; Romaniuk et al. 2017). On the other hand, resistance phenotypes observed for strains without identified resistance genes could be "nonspecific" and resulted from, e.g., altered cell envelope permeability or biofilm formation (Wales and Davies 2015).

Chemical, physiological, and molecular analyses, performed in this study showed that the highest heavy metal concentrations were observed in petroleum-contaminated soil sample (from the Arctowski station, i.e., a strongly anthropogenically shaped site); however, relatively high concentrations of particular heavy metals (e.g., copper) were also observed for other (more pristine) sites, which suggested mineralogical origin of particular metals. Moreover, characterization of over 200 psychrotolerant bacteria revealed the prevalence of heavy metal co-resistance phenotypes and gave an insight into the diversity of heavy metalresistance genes in Antarctic soil ecosystems.

Acknowledgements We thank Jan Gawor from the DNA Sequencing and Oligonucleotide Synthesis Laboratory IBB PAS for his help in DNA sequencing. This work was supported by the National Science Centre (Poland) Grant No. 2013/09/D/NZ8/03046, and partially from the Grant No. N N304 106940.
Author contribution KR and LD conceived and designed the experiments; MZ, DB, and LD coordinated and supervised the analyses; KR, $\mathrm{AC}, \mathrm{PD}, \mathrm{KB}, \mathrm{WU}$, and MN performed the laboratory experiments; JP performed statistical analysis; $\mathrm{MN}$ and $\mathrm{MZ}$ took part in a polar expedition and collected samples; KR, PD, JP, and LD analyzed the data; DB, $\mathrm{MZ}$, and LD contributed reagents/materials/analysis tools; KR, JP, and LD wrote the paper. All authors read and approved the final version of the manuscript.

\section{Compliance with ethical standards}

Conflict of interest The authors declare that they have no conflict of interest.

Open Access This article is distributed under the terms of the Creative Commons Attribution 4.0 International License (http://creativeco mmons.org/licenses/by/4.0/), which permits unrestricted use, distribution, and reproduction in any medium, provided you give appropriate credit to the original author(s) and the source, provide a link to the Creative Commons license, and indicate if changes were made.

\section{References}

Abou-Shanab RA, van Berkum P, Angle JS (2007) Heavy metal resistance and genotypic analysis of metal resistance genes in grampositive and gram-negative bacteria present in Ni-rich serpentine soil and in the rhizosphere of Alyssum murale. Chemosphere 68:360-367

Achour AR, Bauda P, Billard P (2007) Diversity of arsenite transporter genes from arsenic-resistant soil bacteria. Res Microbiol 158:128-137

Adriano DC (2001) Trace elements in terrestrial environments: biogeochemistry, bioavailability, and risks of metals. Springer, New York

Altschul SF, Madden TL, Schaffer AA, Zhang J, Zhang Z, Miller W, Lipman DJ (1997) Gapped BLAST and PSI-BLAST: a new generation of protein database search programs. Nucleic Acids Res 25:3389-3402

Amiard-Triquet C, Rainbow P (2011) Tolerance and the trophic transfer of contaminants. In: Amiard-Triquet C, Rainbow P, Romeo M (eds) Tolerance to environmental contaminants. CRC Press, Boca Raton, pp 299-334

Arazny A, Kejna M, Sobota I (2013) Ground temperature at The Henryk Arctowski station (King George Island, Antratcic)—case study from the period January 2012 to February 2013. Bull Geogr Phys Geogr Ser 6:59-80

Blindauer CA (2011) Bacterial metallothioneins: past, present, and questions for the future. J Biol Inorg Chem 16:1011-1024

Bruins MR, Kapil S, Oehme FW (2000) Microbial resistance to metals in the environment. Ecotoxicol Environ Saf 45:198-207

Chenna R, Sugawara H, Koike T, Lopez R, Gibson TJ, Higgins DG, Thompson JD (2003) Multiple sequence alignment with the Clustal series of programs. Nucleic Acids Res 31:3497-3500

Cowan DA, Makhalanyane TP, Dennis PG, Hopkins DW (2014) Microbial ecology and biogeochemistry of continental Antarctic soils. Front Microbiol 5:154

Curtosi A, Pelletier E, Vodopivez C, St Louis R, Mac Cormack WP (2010) Presence and distribution of persistent toxic substances in sediments and marine organisms of Potter Cove, Antarctica. Arch Environ Contam Toxicol 59:582-592

De Souza MJ, Nair S, Loka Bharathi PA, Chandramohan D (2006) Metal and antibiotic-resistance in psychrotrophic bacteria from Antarctic marine waters. Ecotoxicology 15:379-384 
De Souza MJ, Loka Bharathi PA, Nair S, Chandramohan D (2007) "Trade-off" in Antarctic bacteria: limnetic psychrotrophs concede multiple enzyme expressions for multiple metal resistance. Biometals 20:821-828

Dold B, Gonzalez-Toril E, Aguilera A, Lopez-Pamo E, Cisternas ME, Bucchi F, Amils R (2013) Acid rock drainage and rock weathering in Antarctica: important sources for iron cycling in the Southern Ocean. Environ Sci Technol 47:6129-6136

Drewniak L, Dziewit L, Ciezkowska M, Gawor J, Gromadka R, Sklodowska A (2013) Structural and functional genomics of plasmid pSinA of Sinorhizobium sp. M14 encoding genes for the arsenite oxidation and arsenic resistance. J Biotechnol 164:479-488

Dziewit L, Drewniak L (2016) Heavy metals resistance, metabolism and transformation-genomic, metagenomic and metatranscriptomic studies. In: Dlugonski J (ed) Microbial biodegradation: from omics to function and application. Caister Academic Press, Poole, pp 13-26

Dziewit L, Pyzik A, Matlakowska R, Baj J, Szuplewska M, Bartosik D (2013) Characterization of Halomonas sp. ZM3 isolated from the Zelazny Most post-flotation waste reservoir, with a special focus on its mobile DNA. BMC Microbiol 13:59

Dziewit L, Pyzik A, Szuplewska M, Matlakowska R, Mielnicki S, Wibberg D, Schlüter A, Pühler A, Bartosik D (2015) Diversity and role of plasmids in adaptation of bacteria inhabiting the Lubin copper mine in Poland, an environment rich in heavy metals. Front Microbiol 6:152

Espejo W, Celis JE, Gonzalez-Acuna D, Jara S, Barra R (2014) Concentration of trace metals in excrements of two species of penguins from different locations of the Antarctic Peninsula. Polar Biol 37:675-683

González-Aravena M, Urtubia R, Del Campo K, Lavín P, Wong CMVL, Cárdenas CA, González-Rocha G (2016) Antibiotic and metal resistance of cultivable bacteria in the Antarctic sea urchin. Antarct Sci 28:261-268

Gonzalez-Rocha G, Munoz-Cartes G, Canales-Aguirre CB, Lima CA, Dominguez-Yevenes M, Bello-Toledo H, Hernandez CE (2017) Diversity structure of culturable bacteria isolated from the Fildes Peninsula (King George Island, Antarctica): a phylogenetic analysis perspective. PLoS ONE 12:e179390

Grotti M, Soggia F, Ardini F, Magi E, Becagli S, Traversi R, Udisti R (2015) Year-round record of dissolved and particulate metals in surface snow at Dome Concordia (East Antarctica). Chemosphere 138:916-923

Guerra R, Fetter E, Ceschim LM, Martins CC (2011) Trace metals in sediment cores from Deception and Penguin Islands (South Shetland Islands, Antarctica). Mar Pollut Bull 62:2571-2575

Haferburg G, Kothe E (2007) Microbes and metals: interactions in the environment. J Basic Microbiol 47:453-467

Hooda PS, Tack FMG, Edwards AC, Laing GD, Chen W, Chang AC, Wu L, Page AL, Koo B, Stacey SP, McLaughlin MJ, Hettiarachchi GM, Spurgeon DJ, Schulin R, Johnson A, Frossard E, Evans LJ, Barabash SJ, Lumsdon DG, Gu X, Hough RL, Merrington G, Saikat S, Grosso A, Chaney RL, Broadhurst CL, Centofanti T, Kumpiene J, Arai Y, He ZL, Shentu J, Yang XE, Clifford MJ, Hilson GM, Hodson ME, Pulford ID, Zereini F (2010) Trace elements in soils. Wiley, Chichester

Jerez S, Motas M, Palacios MJ, Valera F, Cuervo JJ, Barbosa A (2011) Concentration of trace elements in feathers of three Antarctic penguins: geographical and interspecific differences. Environ Pollut 159:2412-2419

Kabata-Pendias A, Pendias H (2001) Trace elements in soils and plants. CRC Press, Boca Raton

Kandeler F, Kampichler C, Horak O (1996) Influence of heavy metals on the functional diversity of soil microbial communities. Biol Fertil Soils 23:299-306
Kandeler E, Tscherko D, Bruce KD, Stemmer M, Hobbs PJ, Bardgett RD, Amelung W (2000) Structure and function of the soil microbial community in microhabitats of a heavy metal polluted soil. Biol Fertil Soils 32:390-400

Kelly WJ, Reassey DC (1984) Mercury resistance among soil bacteria: ecology and transferability of genes encoding resistance. Soil Biol Biochem 16:1-8

Kim M, Cho A, Lim HS, Hong SG, Kim JH, Lee J, Choi T, Ahn TS, Kim OS (2015) Highly heterogeneous soil bacterial communities around Terra Nova Bay of Northern Victoria Land, Antarctica. PLoS ONE 10:e0119966

Laluraj CM, Thamban M, Satheesan K (2014) Dust and associated geochemical fluxes in a firn core from coastal East Antarctica and its linkages with Southern Hemisphere climate variability over the last 50 years. Atmos Environ 90:23-32

Lane DJ (1991) 16S/23S rRNA sequencing. In: Stackebrandt E, Goodfellow M (eds) Nucleic acid techniques in bacterial systematics. Wiley, New York, pp 115-175

Lee CK, Barbier BA, Bottos EM, McDonald IR, Cary SC (2012) The inter-valley soil comparative survey: the ecology of Dry Valley edaphic microbial communities. ISME J 6:1046-1057

Lo Giudice A, Casella P, Bruni V, Michaud L (2013) Response of bacterial isolates from Antarctic shallow sediments towards heavy metals, antibiotics and polychlorinated biphenyls. Ecotoxicology 22:240-250

Locarnini SJP, Presley BJ (1995) Trace element concentrations in Antarctic krill, Euphausia superba. Polar Biol 15:283-288

Mangano S, Michaud L, Caruso C, Lo Giudice A (2014) Metal and antibiotic resistance in psychrotrophic bacteria associated with the Antarctic sponge Hemigellius pilosus (Kirkpatrick, 1907). Polar Biol 37:227-235

Mindlin S, Petrenko A, Kurakov A, Beletsky A, Mardanov A, Petrova M (2016) Resistance of permafrost and modern Acinetobacter lwoffii strains to heavy metals and arsenic revealed by genome analysis. Biomed Res Int 2016:3970831

Moghadam MS, Albersmeier A, Winkler A, Cimmino L, Rise K, Hohmann-Marriott MF, Kalinowski J, Ruckert C, Wentzel A, Lale $\mathrm{R}$ (2016) Isolation and genome sequencing of four Arctic marine Psychrobacter strains exhibiting multicopper oxidase activity. BMC Genom 17:117

Moller AK, Barkay T, Hansen MA, Norman A, Hansen LH, Sorensen SJ, Boyd ES, Kroer N (2014) Mercuric reductase genes (merA) and mercury resistance plasmids in High Arctic snow, freshwater and sea-ice brine. FEMS Microbiol Ecol 87:52-63

Morita RY (1975) Psychrophilic bacteria. Bacteriol Rev 39:144-167

Nies DH (2003) Efflux-mediated heavy metal resistance in prokaryotes. FEMS Microbiol Rev 27:313-339

Nieto JJ, Ventosa A, Ruiz-Berraquero F (1987) Susceptibility of halobacteria to heavy metals. Appl Environ Microbiol 53:1199-1202

Pal C, Bengtsson-Palme J, Rensing C, Kristiansson E, Larsson DG (2014) BacMet: antibacterial biocide and metal resistance genes database. Nucleic Acids Res 42:D737-D743

Pearce DA, Newsham KK, Thorne MA, Calvo-Bado L, Krsek M, Laskaris P, Hodson A, Wellington EM (2012) Metagenomic analysis of a southern maritime antarctic soil. Front Microbiol 3:403

Perron GG, Whyte L, Turnbaugh PJ, Goordial J, Hanage WP, Dantas G, Desai MM (2015) Functional characterization of bacteria isolated from ancient arctic soil exposes diverse resistance mechanisms to modern antibiotics. PLoS ONE 10:e0069533

Planchon FAM, Boutron CF, Barbante C, Cozzi G, Gaspari V, Wolff EW, Ferrari CP, Cescon P (2002) Changes in heavy metals in Antarctic snow from Coats Land since the mid-19th to the late20th century. Earth Planet Sci Lett 200:207-222

Pudasaini S, Wilson J, Ji M, van Dorst J, Snape I, Palmer AS, Burns BP, Ferrari BC (2017) Microbial diversity of Browning Peninsula, 
Eastern Antarctica revealed using molecular and cultivation methods. Front Microbiol 8:591

Rahman MH, Sakamoto KQ, Kitamura S-I, Nonaka L, Suzuki S (2015) Diversity of tetracycline-resistant bacteria and resistance gene tet $(\mathrm{M})$ in fecal microbial community of Adélie penguin in Antarctica. Polar Biol 38:1775-1781

Rodriguez-Rojas F, Diaz-Vasquez W, Undabarrena A, Munoz-Diaz P, Arenas F, Vasquez C (2016) Mercury-mediated cross-resistance to tellurite in Pseudomonas spp. isolated from the Chilean Antarctic territory. Metallomics 8:108-117

Romaniuk K, Dziewit L, Decewicz P, Mielnicki S, Radlinska M, Drewniak L (2017) Molecular characterization of the pSinB plasmid of the arsenite oxidizing, metallotolerant Sinorhizobium sp. M14 - insight into the heavy metal resistome of sinorhizobial extrachromosomal replicons. FEMS Microbiol Ecol 93:fiw215

Roosa S, Wattiez R, Prygiel E, Lesven L, Billon G, Gillan DC (2014) Bacterial metal resistance genes and metal bioavailability in contaminated sediments. Environ Pollut 189:143-151

Sambrook J, Russell DW (2001) Molecular cloning: A laboratory manual. Cold Spring Harbor Laboratory Press, New York

Santos IR, Silva-Filho EV, Schaefer CE, Albuquerque-Filho MR, Campos LS (2005) Heavy metal contamination in coastal sediments and soils near the Brazilian Antarctic Station, King George Island. Mar Pollut Bull 50:185-194

Silver S, le Phung T (2005) A bacterial view of the periodic table: genes and proteins for toxic inorganic ions. J Ind Microbiol Biotechnol 32:587-605

Silver S, Misra TK (1988) Plasmid-mediated heavy metal resistances. Annu Rev Microbiol 42:717-743

Silver S, Misra TK, Laddaga RA (1989) DNA sequence analysis of bacterial toxic heavy metal resistances. Biol Trace Elem Res $21: 145-163$

Smith JJ, Tow LA, Stafford W, Cary C, Cowan DA (2006) Bacterial diversity in three different Antarctic Cold Desert mineral soils. Microb Ecol 51:413-421

Tamura K, Stecher G, Peterson D, Filipski A, Kumar S (2013) MEGA6: molecular evolutionary genetics analysis version 6.0. Mol Biol Evol 30:2725-2729

Tang Y, Horikoshi M, Li W (2016) ggfortify: unified interface to visualize statistical result of popular R packages. R J 8:474-485

Tchounwou PB, Yedjou CG, Patlolla AK, Sutton DJ (2012) Heavy metal toxicity and the environment. Exs 101:133-164
Tomova I, Stoilova-Disheva M, Vasileva-Tonkova E (2014) Characterization of heavy metals resistant heterotrophic bacteria from soils in the Windmill Islands region, Wilkes Land, East Antarctica. Pol Polar Res 35:593-607

Tomova I, Stoilova-Disheva M, Lazarkevich I, Vasileva-Tonkova E (2015) Antimicrobial activity and resistance to heavy metals and antibiotics of heterotrophic bacteria isolated from sediment and soil samples collected from two Antarctic islands. Front Life Sci $8: 1-10$

van Dorst JM, Hince G, Snape I, Ferrari BC (2016) Novel culturing techniques select for heterotrophs and hydrocarbon degraders in a subantarctic soil. Sci Rep 6:36724

Vodopivez C, Curtosi A, Villaamil E, Smichowski P, Pelletier E, Mac Cormack WP (2014) Heavy metals in sediments and soft tissues of the Antarctic clam Laternula elliptica: more evidence as a possible biomonitor of coastal marine pollution at high latitudes? Sci Total Environ 502:375-384

Wales AD, Davies RH (2015) Co-Selection of resistance to antibiotics, biocides and heavy metals, and its relevance to foodborne pathogens. Antibiotics 4:567-604

Wang Q, Garrity GM, Tiedje JM, Cole JR (2007) Naive Bayesian classifier for rapid assignment of rRNA sequences into the new bacterial taxonomy. Appl Environ Microbiol 73:5261-5267

Wang Y, Boyd E, Crane S, Lu-Irving P, Krabbenhoft D, King S, Dighton J, Geesey G, Barkay T (2011) Environmental conditions constrain the distribution and diversity of archaeal merA in Yellowstone National Park, Wyoming, USA. Microb Ecol 62:739-752

Wang NF, Zhang T, Zhang F, Wang ET, He JF, Ding H, Zhang BT, Liu J, Ran XB, Zang JY (2015) Diversity and structure of soil bacterial communities in the Fildes Region (maritime Antarctica) as revealed by 454 pyrosequencing. Front Microbiol 6:1188

Zdanowski MK, Weglenski P, Golik P, Sasin JM, Borsuk P, Zmuda MJ, Stankovic A (2004) Bacterial diversity in Adelie penguin, Pygoscelis adeliae, guano: molecular and morpho-physiological approaches. FEMS Microbiol Ecol 50:163-173

Zdanowski MK, Żmuda-Baranowska MJ, Borsuk P, Świątecki A, Górniak D, Wolicka D, Jankowska KM, Grzesiak J (2013) Culturable bacteria community development in postglacial soils of Ecology Glacier, King George Island, Antarctica. Polar Biol 36:511-527 